\title{
ACIL “APOTEKER CILIK”: \\ UPAYA MEMBANGKITKAN EKSISTENSI PROFESI APOTEKER DAN SISTEM INTERPERSONAL EDUCATION PROFESI KESEHATAN SEJAK DINI
}

\author{
Citra Maula Anidya1, Azam Tauf kurrakhman1,Zhulkif i Akbarı, dan Endang \\ Sulistyowati Ningsih 1 \\ Program Studi Farmasi, Fakultas MIPA, Universitas Islam Indonesia, Yogyakarta
}

\section{RINGKASAN}

Apoteker Cilik (ACIL) merupakan sebuah gagasan sebagai upaya dalam membangkitkan eksistensi profesi Apoteker secara lebih nyata. Eksistensi tersebut sangat berpengaruh pada masyarakat yang sampai saat ini masih dipandang sebelah mata. Apoteker adalah salah satu profesi kesehatan yang diakui keberadaaannya oleh UU Tenaga Kesehatan dan pemerintah. Brainding profesi apoteker melalui program Usaha Kesehatan Sekolah (UKS) mulai diperkenalkan pada siswa Sekolah Dasar (SD) agar diketahui eksistensinya. Investasi yang dilakukan sejak dini lambat laun akan berkembang dan menjadi besar. Seperti halnya dokter di Sekolah Dasar yang diidentikkan dengan dengan Dokter Kecil, Apoteker Cilik pun kedepannya akan lebih maju dan dapat membesarkan nama profesi apoteker. Praktik pelaksanaan interpersonal education dapat digunakan sebagai media untuk melakukan kerja sama antar profesi dalam skala kecil. Kemampuan inrepersonal tersebut meliputi kemampuan seseorang untuk mendukung orang lain, memberi dan menerima kritik yang membangun, serta kemampuan bernegosiasi. Oleh karena itu, adanya ACIL sebagai upaya membangkitkan eksistensi profesi apoteker dan international education antar profesi kesehatan sejak dini khususnya di kalangan siswa Sekolah Dasar sangat mendukung guna peningkatan derajat kesehatan masyarakat.

Kata kunci:apoteker cilik,interpersonal education

PENDAHULUAN

Dunia kesehatan Indonseia tidak lebih baikdarinegara-negaralaindiAsia Tenggara. Indeks pembangunan-pun kalah dengan Malaysia dan Vietnam.
Data tahun 2005 menempatkan Indonesia dengan peringkat IPM di posisi 107, dua peringkat di atas Vietnam. Indeks pembangunan manusia itu salah satu indikatornya 
ialah kesehatan. Hal ini menandakan perhatian akan pembangunan kualitas manusia khususnya kesehatan benarbenar diabaikan. Kenyataan tersebut hanyalah sebagian kecil fenomena bahwa kesehatan di negara kita memang bukan sesuatu yang strategis terutama untuk para pengambil keputusan, para pemimpin di negara tercinta ini.

Saat ini kita berada di tahun yang mendekati 2015 dimana seluruh masyarakat dunia mendukung atas pencapaian suatu tujuan ambisius. Tujuan ini dinamakan Millenium Development Goals (MDGs). Pada bulan September tahun 2000, tujuan ini dideklarasikan saat Konferensi Tingkat Tinggi Millenium yang dihadiri oleh pimpinan 189 negara anggota Perserikatan Bangsa-Bangsa (PBB) di New York. Millenium Development Goals merupakan sebuah paket berisi delapan tujuan utama yang memiliki batas waktu tahun 2015 dan target yang sangat terukur. Delapan tujuan itu adalah memberantas kemiskinan dan kelaparan ekstrem, mewujudkan pendidikan dasar untuk semua, mendorong kesetaraan gender dan pemberdayaan perempuan, menurunkan angka kematian anak, meningkatkan kesehatan ibu, memerangi HIV \& AIDS, malaria serta penyakit lain, memastikan kelestarian lingkungan, danmembangunkemitraan global untuk pembangunan.

Apoteker sebagai salah satu tenaga kesehatan telah diakui eksistensinya dilndonesia melalui Peraturan Pemerintah No.51 tahun 2009 tentang pekerjaan kefarmasian. Profesi ini memiliki tanggung jawab dalam pencapaian hal-hal tersebut di atas. Apoteker mempunyai keahlian dan kewenangan dibidang kefarmasian baik di apotek, rumah sakit, industri, pendidikan, dan bidang lain yang berkaitan dengan kefarmasian. Sayangnya, profesi ini kurang diakui keberadaannya oleh masyarakat dibandingkan dengan negara lain. Banyak yang mengatakan kesejahteraan apoteker di Indonesia saat ini sangat memprihatinkan dibanding sepuluh tahun yang lalu (Anonim, 2011).

Penjelasan tersebut menjadi dasar penting diadakannya brainding profesi apoteker sejak dini terutama di kalangan siswa SD. Apoteker Cilik dibentuk agar eksistensinya dapat dikenal seperti profesi dokter dengan program dokter kecil-nya. Selain itu, untuk meningkatkan kecakapan antar profesi kesehatan dalam harmonisasi profesi agar kedepannya tidak ada perselisihan, menumbuhkan rasa solid dalam bekerja sama serta meningkatkan pengakuan dari masingmasing profesi atas ranah kerjanya. Interpersonal education skala kecil dapat direalisasikan melalui program Usaha Kesehatan Sekolah (UKS). Dokter kecil, apoteker cilik serta replika aktivis kesehatan lainnya 
akan dibina dan diberikan pendidikan selayaknya tenaga kesehatan yang nyata sehingga tercipta suasana yang menyehatkan bagi semua orang. Penulisan karya ini bertujuan untuk memberikan gagasan sebagai upaya membangkitkan eksistensi profesi apoteker sejak dini melalui Apoteker Cilik dan menumbuhkan pembelajaran harmonisasi profesi kesehatan sejak dini dalam bentuk interpersonal education skala kecil di tingkat SD.

\section{GAGASAN}

Apoteker sebagai Salah Satu Tenaga Kesehatan

Apoteker merupakan sebuah profesi kesehatan yang diakui keberadaannya oleh UU Tenaga Kesehatan seperti dokter, dokter gigi, perawat, dan bidan (Astika, 2003). Apoteker tergabung dalam IAI atau Ikatan Apoteker Indonesia Indonesia. Mendengar kata "apoteker", mungkin terlintas dalam benak orang ialah "apotek" karena memang kata ini sudah sangat dikenal luas. Untuk menjadi apoteker, seseorang harus melanjutkan pendidikan ke perguruan tinggi dengan memilih program studi farmasiselama 4 tahun atau 8 semester dan mendapatkan gelar Sarjana (sekarang Sarjana Farmasi). Setelah itu menempuh profesi selama 1 tahun untuk menyandang apoteker. Selama menempuh pendidikan baik tingkat sarjana maupun profesi,seseorang lebih banyak mempelajari obat dan segala sesuatu yang terkait dengannya. Mulai dari bahan baku obat, proses pembuatan obat hingga menjadi suatu produk yang bisa digunakan oleh masyarakat, kegunaan atau khasiat obat, cara penggunaan obat, efek samping dari obat, dan lain sebagainya. Dengan kata lain, apoteker merupakan profesi yang seharusnya memiliki pengetahuan paling luas mengenai obat.

\section{Di manakah Profesi Apoteker Bisa Dijumpai}

Sesuai peraturan tentang kefarmasian, apoteker dapat mengabdikan dirinya di beberapa tempat seperti apotek. Menurut peraturan pemerintah, sebuah apotek harus di bawah tanggung jawabapoteker. Di Indonesia, satu apotek umumnya memiliki satu apoteker kecuali pada beberapa apotek besar. Seorang apoteker akan dibantu oleh beberapa tenaga teknis seperti asisten apoteker, juru racik, kasir atau tenaga lainnya. Apoteker akan lebih banyak berkomunikasi dengan pasien yang hendak menebus obat. Kemampuan komunikasi antara apoteker dengan pasien sangatlah penting terkait banyaknya kasus yang terjadi seperti masalah aturan penggunaan, efek samping obat, interaksi obat, kepatuhan pasien dan lainnya. Apabila suatu saat kita menjadi pasien yang menebus obat di apotek, ada baiknya meluangkan waktu sejenak untuk berkonsultasi 
dengan apoteker. Jikalau apotekernya sedang tidak di tempat, pasien dapat membuat janji atau berkonsultasi via telepon dan sebagainya. Apoteker juga banyak bekerja di Rumah Sakit bagian instalasi farmasi dengan letak apotek yang berada di dalam lingkungan Rumah Sakit. Selain itu, apoteker dapat bekerja di pabrik produsen obat maupun kosmetik, di bidang pengawasan obat seperti Badan Pemeriksaan Obat dan Makanan (BPOM).

\section{Kondisi kekinian: Eksistensi} Apoteker yang Terdegradasi

Begitu panjangnya seseorang mendapatkan gelar sarjana farmasi dan rumitnya melakukan praktik kefarmasian, ternyata eksistensi apoteker dikalangan masyarakat masih rendah. Masyarakat mengenal apoteker di apotek sebagai penjual obat. Namun, tidak hanya itu apoteker dapat bekerja di rumah sakit dan melakukan visit ke pasien. Pada kenyataannya hanya rumah sakit tertentu yang telah menerapkan sistem tersebut. Rumah Sakit Daerah yang kapasitasnya masih tergolong rumah sakit kecil belum dapat melaksanakan amanah peraturan pemerintah tersebut dengan berbagai alasan sehingga pamor apoteker-pun kembali dikesampingkan. Disisi lain, sampai saat ini belum ada istilah Apoteker Cilik yang mampu memberikan citra positif bagi profesi apoteker.

\section{ACIL "Apoteker Cilik" : Upaya} peningkatan Eksistensi Profesi sejak Dini

Sebuah terobosan baru sangatlah dibutuhkan ketika eksistensi profesi apoteker menurun untuk mengangkat kembali nama apoteker di kalangan masyarakat. Gagasanyang ditawarkan berupa pembentukan program ApotekerCilik(ACIL). Menilikeksistensi dokter di dunia kesehatan, tidak lepas dari upaya pencitraan profesi dokter sejak dini melalui program Dokter Kecil yang diperkenalkan terutama pada siswa tingkat dasar. Atas dasar itulah apoteker bangkit dengan membangun eksistensinya sejak dini. Program Apoteker Cilik diharapkan menjadi cikal bakal bangkitnya eksistensi profesi apoteker yang dapat direalisasikan di sekolah tingkat dasar.

Apoteker Cilik bertujuan untuk meningkatkan partisipasi peserta didik sebagai upaya pembelajaran mengenai kesehatan khususnya kefarmasian yang dalam praktiknya perlu didukung oleh multi disiplin ilmu dalam wadah program Usaha Kesehatan Sekolah (UKS). Selain itu, Apoteker Cilik juga wahana investasi awal bagi apoteker agar dikenal secara meluas baik dari kalangan anak-anak, remaja maupun dewasa sehingga tidak canggung lagi seorang anak bercita-cita sebagai apoteker. Mereka akan bangga dengan profesi tersebut dan perasaan itu muncul ketika pelaksanaan program Apoteker 
Cilik ini memberikan pengalaman luar biasa atas pekerjaan apoteker.

Usaha Kesehatan Sekolah (UKS): Wahana Interpersonal Education Profesi

Tujuan UKS secara umum ialah meningkatkan kemampuan hidup sehat dan derajat kesehatan peserta didik sedini mungkin serta menciptakan lingkungan sekolah yang sehat sehingga memungkinkan pertumbuhan dan perkembangan anak yang harmonis dan optimal dalam rangka pembentukan manusia Indonesia yang berkualitas (Nemir, 1990). Tujuan secara khusus adalah memupuk kebiasaan hidup sehat dan meningkatkan derajat kesehatan peserta didik yang memiliki pengetahuan, sikap, dan keterampilan melaksanakan prinsip hidup sehat. Sehat secara fsik, mental, sosial maupun lingkungan, serta memiliki daya hayat dan daya tangkal terhadap pengaruh buruk, penyalahgunaan narkoba, alkohol, dan kebiasaan merokok serta hal-hal yang berkaitan dengan masalah pornograf dan masalah sosial lainnya. UKS dikelompokkan menjadi tiga kegiatan pokok (Lucky, 1992), yaitu: Pendidikan kesehatan di sekolah (health education in school), Pemeliharaan kesehatan sekolah (school health service), dan Lingkungan sekolah yang sehat. Dari kegiatan pokok itulah Apoteker Cilik dibina dan dididik untuk menunjukkan eksistensinya sebagai salah satu tenaga kesehatan yang berkualitas. Tidak dipungkiri juga kemungkinan adanya kerjasama antara dokter kecil dengan apoteker cilik untuk mencapai tujuan kesehatan di lingkungan sekolah sesuai yang diharapkan.

\section{Interpersonal Education yang} dibutuhkan dalam Bidang Kesehatan

Kemampuan interpersonal berkaitan erat dengan kemampuan bekerjasama dengan orang lain. Hal ini meliputi kemampuan siswa untuk mendukung orang lain, memberi dan menerima kritik yang membangun, serta kemampuan bernegosiasi. Kemampuan interpersonal juga berkaitan dengan kemampuan mengolah hard-skill secara luas untuk mendapatkan soft-skill yang mahir, mampu menggerakkan dan mengisi semua potensi indrawi seperti tangan, kaki, lidah, rasa, cipta, dan karsa untuk menjalankan kehidupan sehari-hari. Hal ini akan lebih baik jika dilatih sejak dini. Program interpersonal education yang digagas melalui kerjasama Dokter Kecil dan Apoteker Cilik dinilai sangat layak sebagai wahana pendidikan antar profesi dikalanganSekolah Dasar melalui program Usaha Kesehatan Sekolah (UKS).

Pihak-Pihak yang Terkait Pelaksanaan Gagasan

Beberapa pihak yang dapat 
memberikan kontribusi dalam (Lucky, 1990), dan petugas kesehatan pelaksanaan gagasan ini ialah siswa puskesmas atau profesi kesehatan SD tingkat 4-6 untuk menjadi Apoteker lain (Anonim, 2011, Nasrul, 1997). Cilik, dewan guru dan pembina UKS

\section{Langkah-Langkah Mengimplementasi Gagasan}

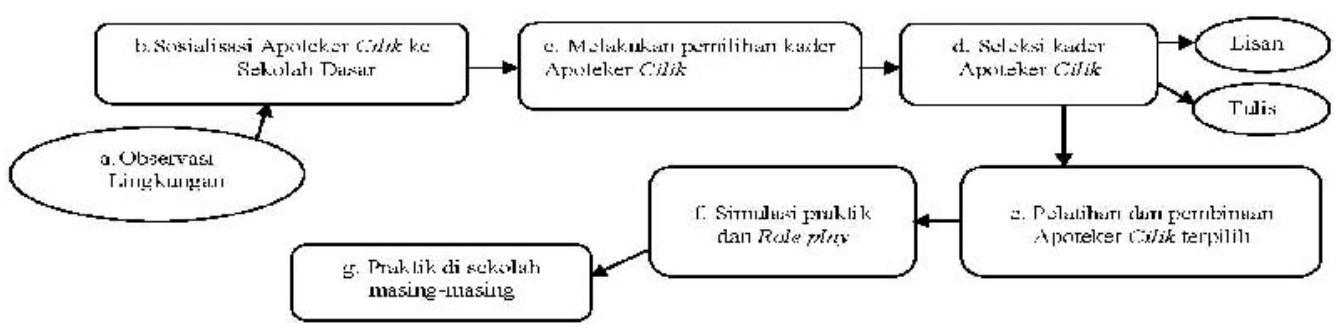

\section{KESIMPULAN}

Apoteker Cilik merupakan sebuah gagasan sebagai upaya dalam membangkitkan eksistensi profesi Apoteker secara lebih nyata sejak dini. Melalui kerjasama antara Dokter Kecil dan Apoteker Cilik, sistem interpersonal education dinilai sangat layak sebagai wahana pendidikan antar profesi khususnya di Sekolah Dasar yang dilaksanakan melalui Usaha Kesehatan Sekolah (UKS). Gagasan ini diharapkan dapat meningkatkan citra positif profesi apoteker di masyarakat sehingga tercipta suasana lingkungan yang menyehatkan bagi semua orang.

DAFTAR PUSTAKA

Anonim., 2011, Menjadi Profesi Apoteker Yang Tangguh, Ikatan Apoteker Indonesia, http://www. ikatanapotekerindonesia.net/ articles.html (diakses 25 April 2012).

Astika, S.L., dalam Charles, S., dan Lia, A., 2003, Farmasi Rumah Sakit : Teori Dan Terapan, EGC, Jakarta, 177-178.

Lucky, H., 1992, Hubungan program Dokter Kecil dengan pengetahuan, sikap dan praktek kebersihan perorangan pada siswa-siswa Sekolah Dasar Negeri di Kotamadya Yogyakarta tahun 1990, Thesis, Jurusan Kesehatan Masyarakat Fakultas Kedokteran, Universitas Indonesia, Bogor.

Nasrul, E., 1997, Dasar-dasar Keperawatan Kesehatan Masyarakat: edisi II, EGC, Jakarta, 110-112.

Nemir., 1990, dalam Efendy, Program Usaha Kesehatan Sekolah, USU, Medan. 